\title{
Bedömningar för anpassning i tidig läsundervisning: Lärares erfarenheter av att utveckla elevers avkodningsförmåga
}

\author{
Ulrika B. Andersson \\ Linköpings Universitet, Institution för beteendevetenskap och lärande \\ Håkan Löfgren \\ Linköpings Universitet, Institution för Tema
}

\begin{abstract}
I artikeln studeras svenska förskoleklasslärare och lågstadielärares lärares användning av bedömningsinformation som underlag för att göra anpassningar i tidig läsundervisning med fokus på avkodning. Avsikten är att bidra med kunskap till två skilda forskningsfält, framåtsyftande bedömning och avkodningsundervisning. Vi har intervjuat 12 lärare och uppmuntrat dem att berätta om sitt arbete med att utveckla sina elevers avkodningsförmåga inom ramen för ett lokalt utvecklat läsprojekt inriktat på avkodningsträning. Genom narrativa analyser har vi studerat lärarnas berättelser om sitt arbete med bedömning och anpassning. I resultatdelen presenterar vi tre berättelser som illustrerar olika typer av bedömnings- och anpassningshandlingar samt hur dessa motiveras av lärarna. I diskussionen belyser vi tre olika perspektiv som framträder i lärarnas motiveringar och diskuteras betydelsen av att lärare anpassar sin undervisning på skilda sätt utifrån de bedömningar lärarna berättar att de gör samt hur de motiverar sina handlingar. Studiens resultat visar att såväl kognitiva som sociala bedömningsaspekter beaktas av lärarna när de anpassar avkodningsundervisningen. Det framgår också att lärarnas arbete med att bedöma och anpassa avkodningsundervisningen inom ramen för det stöd som läsprojektet utgör ställer höga krav på lärares professionella kompetens och kunskaper.
\end{abstract}




\section{BEDÖMNINGAR FÖR ANPASSNING I TIDIG LÄSUNDERVISNING: \\ LÄRARES ERFARENHETER AV ATT UTVECKLA ELEVERS \\ AVKODNINGSFÖRMÅGA}

I den här artikeln intresserar vi oss för de framåtsyftande bedömningar lärare gör i samband med att de undervisar om avkodning och hur dessa bedömningar används för att anpassa undervisningen så att nybörjare $\mathrm{i}$ lågstadiet lär sig läsa.

I svensk skola uppmuntras lärare att genomföra formativa bedömningar som ska leda till anpassningar av undervisningen. Lärarens förmåga att göra bedömningar och att använda dem för att anpassa sin undervisning på ett sätt så att den bidrar till utveckling av elevers lärande är att betrakta som en nyckelkompetens (Giota, 2002; Jönsson, 2017) och att lärare kan motivera sina handlingar i klassrummet betraktar vi som ett uttryck för lärares professionalism (Colnerud \& Granström, 2015). Det finns dock få studier med inriktning mot fältet formativa bedömningar som intresserar sig specifikt för hur lärare använder bedömningar för att stärka elevers förmåga att avkoda (Heritage, 2013; Hirsh \& Lindberg, 2015; Lindberg m.fl., 2019; Prøitz m.fl., 2017; Westlund, 2013) och forskningen har endast i någon mån intresserat sig för hur lärare motiverar sina handlingar i samband med bedömningar och anpassningar i svenskämnet.

Att lära sig läsa ställer inledningsvis höga krav på elevers avkodningsförmåga, det är därför angeläget att lärare i sitt arbete med läsundervisning ägnar uppmärksamhet åt att tidigt identifiera nybörjarläsarens behov av stöd för att kunna anpassa undervisningen (Gough \& Tunmer 1986; Høien \& Lundberg, 2013; National Reading Panel, 2000). Bedömningar som avser att utveckla avkodningsförmåga är därför, menar vi, av stor betydelse för den tidiga läsundervisningen. Många svenskdidaktiska studier adresserar frågan om hur undervisning och metoder kan utvecklas för att elever ska träna sin förmåga till avkodning, men de länkar sällan metoderna till den detaljerade information lärare, genom sina olika bedömningar, har om elevernas kunskapsnivå. I den här studien vill vi försöka överbrygga gapet mellan forskning om framåtsyftande bedömningar (Andersson m.fl., 2019; Jönsson, 2017) och forskning om undervisningsinsatser för förbättrad avkodning (Taube m.fl., 2015).

För att stödja svenska lärares arbete med tidig läsundervisning är det vanligt med olika former av läsprojekt. En sökning på "läsprojekt i lågstadiet" och "läsa i lågstadiet" med hjälp av Google påvisar en rad projekt med syfte att stödja lärares arbete med elevers läsutveckling. Det framgår av projektbeskrivningarna på nätet att storleken på projekten och den geografiska spridningen skiljer sig åt. Det finns lokalt organiserade projekt för enstaka skolor eller skolområden (Gerby skola; Attagardenslasprojekt) men även projekt som organiseras på kommunnivå (i Burlövs kommun; Pedagog- 
Uddevalla; PedagogStockholm) och på nationell nivå (Lasrorelsen.nu). Utöver läsprojekten som vi använder för att exemplifiera ett vanligt fenomen finns också bedömningsstöd på nationellnivå, till exempel; God läsutveckling (Lundberg \& Herrlin, 2014b), LegiLexi (LegiLexi.se), Nya språket lyfter (Skolverket.se) och Hitta språket, obligatoriskt i åk 1 (Skolverket.se). Gemensamt för läsprojekt och bedömningsstöd är att de syftar till att utveckla elevernas läsförmåga genom att stödja lärares arbete med tidig läsundervisning. Hur detta görs skiljer sig åt. En del läsprojektsbeskrivningarna på nätet handlar om en specifik metod, till exempel högläsning med stöd av boklådor. Andra beskriver att uppmärksamheten riktas mot en bestämd förmåga (till exempel avkodningsförmåga). En del läsprojektbeskrivningar innehåller information om för- och eftertest andra läsprojektsbeskrivningar lämnar ingen sådan information. De nationella bedömningsstöden är framförallt inriktade på att stödja läraren $i$ att identifiera elevernas kognitiva nivå för framåtsyftande ändamål. I den här studien använder vi data från ett läsprojekt som utvecklats lokalt i ett rektorsområde.

Syftet med studien är att bidra med kunskap om lärares arbete med att använda bedömningsinformation som underlag för anpassningar i läsundervisning med fokus på avkodning.

Vi studerar specifikt de bedömnings- och anpassningshandlingar lärare berättar att de gör och hur de motiverar dessa handlingar inom ramen för ett lokalt läsprojekt för att utveckla elevernas förmåga att avkoda. Projektet kallas "Träningslägret" eftersom de skolor som ingår gör gemensamma anpassningar för avkodningsträning, baserade på standardiserade avkodningstest, som liknas vid träningsmoment i idrottsvärlden. Avkodningstestet som heter H4 är ett ofta använt och välbeprövat avkodningstest. Resultat från testen före och efter genomfört Träningsläger läsåret 2018/2019 visar, enligt de två deltagande skolorna, att eleverna förbättrat sin avkodningsförmåga. I den här studien analyseras lärares berättelser om sitt arbete med standardiserade och individuella bedömningar, och med standardiserade och individuella anpassningar. Standardiserade bedömningar är de beslutade gemensamma bedömningar som görs före och efter Träningslägret, till exempel avkodningstestet (H4) som ligger till grund för projektets utformning och innehåll, och Hitta språket (Skolverket.se). Med standardiserade anpassningar menar vi Träningslägrets fyra moment med fastställt innehåll (vi återkommer till dessa längre fram). Med individuella bedömningar avses lärarnas egna förfinade och detaljerade bedömningar som i huvudsak görs under projektets gång. Individuella anpassningar är de anpassningar som görs utanför den planerade och standardiserade läsprojektsramen Träningslägret.

I enlighet med Mavrommatis (1997) betraktar vi lärarnas bedömningsarbete som en process där insamling av information om elevers kunskaper, bedömning av insamlad information och anpassningar av undervisningen utgör centrala delar. Genom att använda en narrativ metod vill vi bidra med 
kunskap om hur lärare gör olika bedömningar där information tolkas och ligger till grund för anpassningar, som enligt lärarna, bidrar till förbättrad avkodningsförmåga hos eleverna. Ett särskilt intresse riktas mot hur de motiverar sina handlingar, eller med andra ord, vad de själva ser som den huvudsakliga poängen med att göra de anpassningar de gör. Studien besvarar följande frågeställningar:

a) Vilka bedömnings- och anpassningshandlingar berättar lärarna att de gör $\mathrm{i}$ arbetet med att utveckla elevernas avkodningsförmåga inom ramen för "Träningslägret"?

b) Hur motiverar lärarna att bedömnings- och anpassningshandlingarna leder till förbättrad avkodningsförmåga?

c) Hur menar lärarna att deras bedömningar leder till "rätt anpassning"?

Inledningsvis presenteras forskning om avkodning i tidig läsundervisning, framåtsyftande bedömning samt specifik bedömning och anpassning för avkodning. Därefter beskrivs den specifika kontexten som "Träningslägret" utgör. I resultatdelen presenteras tre berättelser som illustrerar hur olika bedömningsaspekter leder till de anpassningar som lärarna anser är viktiga för att deras elever ska lära sig avkodning. Avslutningsvis diskuteras betydelsen av att lärare anpassar sin undervisning på kvalitativt skilda sätt utifrån de bedömningar de gör samt hur de motiverar sina handlingar. Detta ställs $i$ relation till tidigare forskning om framåtsyftande bedömning och till studier om avkodning.

\section{Avkodning i tidig läsundervisning}

Läsning, eller läsförståelse, beskrivs genom The Simple view of reading (SVR) som produkten av de båda faktorerna avkodningsförmåga och språkförståelse (Gough \& Tumner, 1986), båda anses nödvändiga för att uppnå god läsförståelse (Lonigan et al., 2018). I linje med SVR betonar vi de båda faktorernas betydelse för läsförståelse, men riktar här uppmärksamheten endast mot avkodningsförmågan eftersom den har störst betydelse tidigt $\mathrm{i}$ läsundervisningen (Ehri, 2020; Elwér, 2014; Høien \& Lundberg, 2013). I takt med att avkodningsförmågan utvecklas kan mer av läsarens energi läggas på textens innehåll och då får språkförståelsen en allt större betydelse för elevens läsutveckling (Elwér, 2014; Hjetland, et. al., 2017; Hjetland, et. al.,2019).

Att avkoda betyder att tolka bokstavstecken till ord och typisk avkodningsutveckling kan delas in i följande fyra faser; pseudoläsning, logografisk läsning, alfabetisk-fonologisk läsning och ortografisk-morfemisk läsning (Høien \& Lundberg, 2013). Alfabetisk-fonologisk och ortografisk-morfemisk läsning är de faser där bokstavssymbolerna börjar används som representanter för språkljud (Alatalo, 2011). Det innebär att fokus riktas på grafem-fonem kopplingar och hur dessa ljudas ihop till ord, samt läsning där 
delar av ord eller hela ord läses som minnesbilder. Målet med lästräningen är snabb, säker och automatiserad avkodning, vilket också benämns "att läsa med flyt". Utmärkande för den skickliga avkodaren är också förmågan att kunna växla mellan olika avkodningsstrategier utifrån behov. Eleven avkodar då främst ortografiskt, men kan övergå till alfabetisk-fonologisk avkodning och ljuda när svåra eller obekanta ord dyker upp i texten (Alatalo, 2011; Høien \& Lundberg, 2013).

Det finns olika metoder för att träna på avkodning (Fridolfsson, 2016; Lundberg \& Herrlin, 2014a). Snow och Juel (2005) menar att alla barn gynnas av avkodningsträning tidigt $\mathrm{i}$ läsundervisningen, ingen tar skada av den, men för några barn är den helt avgörande. Det framgår att det väsentliga är att undervisningen är strukturerad och balanserad och tar hänsyn till elevens behov (Alatalo, 2011; Fridolfsson, 2016; Høien \& Lundberg, 2013).

Läsmotivation (Høien \& Lundberg, 2013) och självförtroende (Taube, 2007) är ytterligare faktorer som har betydelse för elevens läsutveckling, inte minst när det handlar om att lära sig avkoda. Høien och Lundberg (2013) som förespråkar färdighetsträning lyfter dock betydelsen av att balansera denna typ av träning för att inte riskera att den upplevs som enformig och utan mening vilket kan inverka negativt på elevens läsmotivation. Taube (2007) uppmärksammar elevers svårigheter och känsla av misslyckanden i samband med tidig läsundervisning och menar att sådana situationer kan leda till att eleven får dåligt självförtroende. Något som kan påverka elevens läsmotivation negativt och leda till att strategier för att slippa läsa utvecklas (Taube, 2007).

\section{Framåtsyftande bedömning}

Väsentligt för framåtsyftande bedömningar är att den information, eller data, som samlas in och är kopplad till elevens kunskapsutveckling används av läraren (alternativt av eleven själv eller en kamrat) för att antingen göra anpassningar av undervisningen, eller för att ge återkoppling till eleven (Fuchs \& Fuchs, 2006; Grigorenko, 2009; Sadler, 1989; Wiliam, 2011). I den här artikeln ställer vi våra resultat $i$ relation till forskning om formativ bedömning (FB) och Response to intervention (RTI) vilka båda är väletablerade förhållningssätt för framåtsyftande bedömningar som används i klassrumskontext (Andersson m.fl., 2019). Den formativa bedömningspraktiken inkluderar såväl lärares bedömningar som självbedömning och kamratbedömning. Vi fokuserar på bedömningar som görs av lärare $i$ syfte att utveckla sin undervisning (Heritage, 2013; McMillan, 2017; Prøitz, m.fl., 2017). Formativ bedömning (FB) utmärks av att läraren själv ansvarar för att besluta om; vilken bedömningsmetod som ska användas; vad som ska bedömas och vem som ska bedöma. Även när och hur bedömningarna genomförs är den enskilda lärarens beslut, liksom hur bedömningarna tolkas och används antingen för att anpassa undervisningen eller som feedback till 
elever på individnivå. Formativ bedömning är möjligt att använda $i$ alla skolämnen och på olika vis, hur det formativa bedömningsarbetet följs upp beslutas av läraren och kan se olika ut (Heritage, 2013; Wiliam, 2011). I FB förespråkas lärar-elev dialog och tydligt uttryckta kunskapsmål för att möjliggöra elevens delaktighet och ansvarstagande $\mathrm{i}$ det egna lärandet. Response to intervention (RTI) utmärks av en målstyrd och tydlig struktur med systematisk och återkommande testning av elevers förmågor (Fuchs \& Fuchs, 2006). För detta används standardiserade test som avser att identifiera elevernas svårigheter på detaljnivå inom ett specifikt skolämne (till exempel avkodningsförmåga). Testresultaten ligger till grund för interventioner där eleven får öva på de färdigheter där testen påvisat brister. Interventionerna är indelade i olika nivåer (tiers) vilka inkluderar undervisningsinnehåll och graden av individualisering genom undervisning $i$ klass, grupp eller individuellt. Efter genomförd intervention "enligt RTI strukturen" ska läraren genomföra uppföljande test för att kontrollera effekten av interventionen och för att få vägledning inför fortsatt undervisning (Fuchs \& Fuchs, 2006).

\section{Bedömning och anpassning för avkodning}

Bedömning som ger information om elevens avkodningsförmåga och bidrar med att identifiera svårigheter framträder som grundläggande för arbetet med att stödja och utveckla avkodningsförmåga (Fälth m.fl., 2015; Gustafson m.fl., 2007; Høien \& Lundberg, 2013; National Reading Panel, 2000; Wolff, 2016). Hur testresultat kan användas för att bedöma elevers förmågor i syfte att anpassa avkodningsundervisningen synliggörs $i$ en interventionsstudie av Fälth m.fl. (2015) som undersökt effekten av avkodningsträning med ordlistor. Interventionen inkluderade också stöd från speciallärare. Stödet grundades på lärarens bedömning där och då och bestod i att läraren uppmärksammade eleven på felläsning och uppmuntrade nya försök. Tidigare studier visar att välstrukturerad intensivundervisning med fokus på fonemgrafem koppling ger positiva resultat avseende elevers avkodningsförmåga (Ehri m.fl., 2001; Høien \& Lundberg, 2013; National Reading Panel, 2000; Wolff, 2011). Färdighetsträning som genomförs en till en, lärare-elev, har större positiv påverkan på elevens avkodningsutveckling än då två elever genomför träningen tillsammans (Taube m.fl., 2015). Läslistorna som användes i Fälth m.fl., (2015) studie bestod av olika kategorier som användes för att anpassa listornas innehåll efter elevens träningsbehov baserade på test av deras kognitiva förmågor: från grafem, enkla ord, pseudo-ord, stavelser, högfrekventa småord, ljudenligt- och ljudstridigt stavade ord, vokaler, konsonantförbindelser till ändelser och dubbelteckning för att nämna några.

För att bli en god läsare krävs träning på rätt saker (Castles et al., 2018). Morgan och Fuchs (2007) uppmärksammar sambandet mellan läsmotivation, lästräning och goda läsare. En läsmotiverad elev väljer oftare att läsa än en elev som saknar läsmotivation. Den redan läsmotiverade eleven har därför 
större chans att utvecklas till en god läsare till skillnad från den omotiverade (jfr Matteuseffekten). En alltför ensidig träning, även om den likt upprepad läsningen av ord-listor visat på positiva resultat, kan riskera att påverka elevens läsmotivation negativt och måste då på något vis uppmärksammas för att vägleda en förändring av den fortsatta träningen (Høien \& Lundberg, 2013). Det finns få tidigare studier om avkodningsundervisning som likt föreliggande fokuserar på bedömningar av andra aspekter än de kognitiva och inga tidigare studier har beaktat hur lärare resonerar och motiverar sina bedömningar och anpassningar i denna kontext.

\section{METOD}

Vi har valt narrativ metodansats och analysmodell för att studera hur lärare använder bedömning inom den specifika kontext som här utgörs av hur lärare använder bedömning för att utveckla elevers avkodningsförmåga inom ramen för ett lokalt läsprojekt. Goodson och Sikes (2001) menar att det primära syftet med en narrativt inriktad ansats är att undersöka hur människor, enskilda eller i grupper, förstår och skapar identitet och mening i sina liv. Vi använder narrativ ansats för att genom berättelser närma oss studiens lärare, deras erfarenheter och meningsskapande inom ramen för läsprojektet. Vi, i likhet med Goodson och Sikes (2001), betraktar berättelser som en viktig källa till kunskap om lärares professionella arbete och är genuint intresserade och nyfikna på vad studiens lärare vill och kan berätta.

I likhet med med Mishler (1999) och Perez Prieto (2006) ser vi berättelser som sociala konstruktioner och meningsskapande handlingar. Det betyder att berättelser är dialogiska och tar form i mötet mellan berättare och lyssnare i en specifik kontext (Mishler, 1999). Vi menar att berättelserna kan bidra med kunskap om lärares erfarenheter och meningsskapande som kan tolkas i relation till sin kontext.

För studiens berättelser är läsprojektet Träningslägret en del av den lokala skolkontexten (vi återkommer till detta under rubriken Träningslägret - ett lokalt projekt och en specifik kontext), dit hör även aspekter som synliggjordes vid våra inledande skolbesök, till exempel; skolområdets placering på landsbygden, behöriga lärare, uttalad sårbarhet kopplad till organisationsstorleken, egenuttalad hög måluppfyllelse, ett identifierat behov av avkodningsträning, både åldershomogena och icke åldershomogena klasser med ett varierat elevantal samt en uttalat positiv och intresserad inställning till forskningsstudien. Den lokala skolkontexten ramas in av en svensk skolkontext, där Skollag och läroplaner utgör ett ramverk (SFS 2010:800; Skolverket, 2019). Till det kan fogas en framväxande bedömningskultur där bedömningar och resultatjämförelser mellan skolor och länder ökat under 2000-talet (Hirsh \& Lindberg, 2015; Pettersson, 2010). Exempel på en sådan ökning som berör studien är de rapporter baserade på resultat från nationella 
prov och PISA-mätningar som under flera år visat på svenska elevers sjunkande läsförmåga (www.skolverket.se). Ett annat exempel är införandet av obligatorisk kartläggning av läs- och matematikförmågor $\mathrm{i}$ lågstadiet (Skolverket, 2021).

De första skolbesöken som genomfördes för att få information inför den eventuella studien bidrog, förutom till förståelse och meningsskapande i analysarbetet, också till utformningen av intervjuguiden.

\section{Urval}

Data i den här studien hämtas från ett lokalt läsprojekt, på en F-årskurs 3 skola och en F-årskurs 6 skola, som väckte intresse eftersom skolornas egna mätningar påvisade en positiv utveckling av så gott som samtliga medverkande elevers avkodningsförmåga. En starkt bidragande orsak till vårt beslut att genomföra studien på dessa skolor var alltså de positiva bedömningsresultat från för- och eftermätningar kopplade till Träningslägret, som skolutvecklingsgruppen berättade om vid vår första kontakt. Skolornas mätmetoder var dock inte genomförda på ett vetenskapligt och helt systematiskt sätt och redovisas därför inte i denna artikel. Vi såg det också som positivt att Träningslägret vid tiden för studien genomfördes för tredje gången, vilket vi menar bidrar till en viss kontinuitet $i$ genomförandet. Ytterligare en faktor som bidrog till vårt val av just dessa skolor var skolutvecklingsgruppens (rektor, utvecklingsledare och lärare) starka engagemang för läsutveckling baserad på bedömningar och deras intresse av att delta i studien.

Studiens fokus på tidig läsinlärning låg till grund för valet av lärare kopplade till förskoleklass, årskurs 1-3 och fritidshem. Samtliga lärare som arbetade med åldersgruppen tillfrågades och samtliga valde att delta. I studien medverkar 12 lärare varav 2 förskollärare, 8 lärare i årskurs 1-3 var av 3 stycken med specialpedagogisk kompetens och 2 lärare från fritidshemmet. Skolledningens beslut om att frigöra lärarna under lektionstid för att möjliggöra deras medverkan $\mathrm{i}$ studien, uttrycktes som positivt av våra informanter och bidrog säkert till högt deltagande. De tre berättelser som presenteras i artikeln har valts ut eftersom de illustrerar en spännvidd avseende olika typer av bedömnings- och anpassningshandlingar i såväl förskoleklass som i de tidiga skolåren.

\section{Narrativ intervju}

För att få kunskap om hur lärare anpassar sin undervisning i relation till gjorda bedömningar har vi använt oss av öppna, semistrukturerade intervjuer där lärare uppmanas att berätta om och ge exempel från sitt arbete (Goodson \& Sikes, 2001). I likhet med Perez Prieto (2006) menar vi att poängen med att använda berättelser är just 'vad' lärarna berättar om sina upplevelser inom en specifika kontext. Vi bad informanterna att exemplifiera genom att använda 
konkreta handlingar från Träningslägerpraktiken. Inför intervjuerna informerades lärarna skriftligt och muntligt om studien. I planeringsarbetet var vi angelägna om att organisera intervjusituationen för varje enskild lärare så att den skulle upplevas som bekväm, vi anpassade oss efter deras önskemål avseende tid och plats. Vi var också medvetna och angelägna om att skapa en positiv atmosfär där vi intog en nyfiken och lyssnande roll (Goodson \& Sikes, 2001). De individuella intervjuerna genomfördes på skolorna under dagtid, 2 timmars arbetstid per intervju var avsatt för detta, vilket vi menar är gott om tid för att skapa en avspänd atmosfär. En intervjuguide användes som stöd. Vanliga frågor och uppmaningar som användes under intervjuerna var; "Berätta om...?" och "Hur gör du då, berätta?", avsikten var att likt Goodson och Sikes (2001) uppmuntra lärarna att berätta om sina praktiska erfarenheter. Inom ramen för den narrativa intervjuformen fanns möjligheten för informanterna att be oss förtydliga frågor om något var oklart. Den möjligheten använde även vi, liksom möjligheten att fånga för studien intressanta aspekter som uppstår i stunden och av sammanhanget, eller att återkomma till en fråga om det fanns behov av tillägg i någon form (Goodson \& Sikes, 2001). Intervjuerna spelades in på diktafon och har transkriberats $i$ sin helhet. I parenteser angavs ljudfilens tidsangivelse vilket har underlättat analysarbetet då vi lyssnat på vissa sekvenser vid upprepade tillfällen.

\section{Narrativ ansats och analys}

Studien har en narrativ ansats vilket gör det möjligt att studera hur lärare, i sina berättelser om gjorda bedömningar och anpassningar, motiverar de handlingar de anser bidrar till förbättrad avkodningsförmåga hos eleverna. Berättelserna betraktas som sociala konstruktioner och som meningsskapande handlingar (Mishler,1999; Perez Prieto, 2006), där lärarnas motiveringar till gjorda bedömningar och anpassningar kan studeras. Genom att studera lärares berättelser, det vill säga vad lärare berättar om sina konkreta sammanhang, bidrar studien med detaljerad kunskap om de många klassrumsbedömningar och anpassningar som lärarna menar att de gör i relation till specifika elever eller grupper inom ramen för läsprojektet. I analysen fyller temporaliteten, tidsordningen, en viktig funktion då den gör det möjligt att identifiera narrativa enheter i berättelsen (Labov \& Waletzky, 1967/1997). Olika bedömnings- och anpassningshandlingar knyts till varandra och organiseras på ett sätt som ger dem mening $i$ relation till varandra och som gör det möjligt för berättaren att dra sina slutsatser om varför just dessa handlingar var relevanta. Den temporala logiken är alltså att en bedömningshandling följs av en anpassningshandling som motiveras med att den, enligt läraren, bidrar till att en elev lär sig avkoda bättre.

Analysen genomfördes i tre steg. Först identifierades lärares bedömningshandlingar i transkripten. Dessa kännetecknas av att läraren på något sätt samlar in information om eleverna som har betydelse för en anpassning som 
sedan görs. Bedömningshandlingarna kan fokusera på en individ, ett par eller en grupp av elever, eller på samtliga elever som deltar i projektet. Bedömningshandlingarna kan vidare riktas mot elevers kognitiva färdigheter, mot deras agerande i klassrummet, eller mot dem som individer (McMillan, 2017). Gemensamt för samtliga bedömningshandlingar som studeras är att de är framåtsyftande, de ligger till grund för en nära förestående anpassning som är motiverad av läraren. I nästa steg $\mathrm{i}$ analysen urskiljs de narrativa enheterna i lärarnas berättelser genom att studera hur bedömningshandlingarna leder till specifika anpassningshandlingar. Då anpassningshandlingarna, enligt lärarnas berättelser, bidrar till att eleverna blir bättre på avkodning, är det centrala här att försöka förstå hur, på vilket sätt, läraren kommer fram till att detta är de mest lämpliga anpassningarna. Även anpassningshandlingar är framåtsyftande och sker på individ, par eller gruppnivå. Det tredje analyssteget rikas mot de motiveringar som framträder i lärarnas berättelser och som kopplas till specifika bedömnings- och anpassningshandlingar. Varje narrativ enhet som studeras avslutas med en evaluering och resolution (Labov \& Waletzky, 1967/1997) där läraren tillskriver berättelsen en viss betydelse som har en grad av allmängiltighet. I detta fall handlar betydelsen om hur läraren motiverar att specifika bedömnings- och anpassningshandlingar faktiskt leder till att elever blir bättre på att avkoda. Lärarna framträder som professionella när de retrospektivt förklarar och motiverar varför vissa bedömningar leder till specifika anpassningar som har ett värde även utanför den specifika situationen. Resultaten i den här studien illustrerar kvalitativa skillnader i de bedömningar och anpassningar som lärare i projektet gör och som framträder tydligt i de tre berättelser som valts ut.

\section{Forskningsetiska överväganden}

Etiska ställningstaganden är viktiga och gällande under hela vårt arbete med studien. I vårt arbete med detta har vi utgått från Vetenskapsrådets (2017) riktlinjer för god forskningssed inom humaniora och samhällsvetenskap. De lärare som deltar i projektet har fått muntlig och skriftlig information om studien, dess syfte, datamaterialets användning och förvaring samt den färdiga studiens publicering och övrig eventuell användning. För att studiens informanter ska förbli anonyma är vi sparsamma med beskrivningar av miljöer. Vi använder inte namn på platser eller personer. Däremot skriver vi vilken årskurs eller årskurser de olika lärarna undervisar i eftersom vi menar att det utgör en del av kontexten.

\section{Träningslägret - ett lokalt läsprojekt och en specifik kontext}

Läsutvecklingsprojektet "Träningslägret" började med att lärarna på två landsbygdsskolor uppmärksammade elevernas sjunkande läsförmåga. De genomförde standardiserade avkodningstest vilka sedan låg till grund för utformandet av läsprojektet. Tanken med det var att ta ett gemensamt och 
kraftfullt tag i elevernas avkodningsförmåga. Träningslägret kan beskrivas som en generell insats med fastställd struktur för bedömningsarbetet och standardiserat anpassade undervisningsmoment för varierad avkodningsträning. Träningslägret ramas in av för- och eftertest $(\mathrm{H} 4)$ som avser att mäta avkodningsförmågan. Resultaten från förtesten tillsammans med resultat och bedömningsinformation från obligatoriskt bedömningsstöd i svenska och kartläggningsmaterial från Skolverket fungerar som underlag för anpassningar genom standardiserade träningsmoment, eller anpassningar för eleverna. Träningslägret hade 2018, vid tiden för den här studien, genomförts två gånger och resultaten från eftertesten som gjorts visar enligt de ansvariga på positiv avkodningsutveckling på individnivå. Träningslägret genomförs under en 4-veckorsperiod i anslutning till varje terminsstart. Förskoleklass och årskurserna 1-3 följer en gemensamt fastställd struktur med dagliga standardiserade anpassningar baserade på bedömningsresultaten. De olika anpassningarna kallas gemensamt för "träningspass" och genomförs i huvudsak parvis under 20 minuter. Varje träningspass består av fyra delmoment: 1) Uppvärmning. Momentet innebär att eleverna läser nivåanpassade listor med ord högt för varandra. 2) Match. Högläsning. Eleverna i paret turas om att läsa högt för varandra ur varsin likadan bok. 3) Teknikträning. Ett handskrivningsmoment där eleverna skriver av en del av den text de just läst. 4) Snack med coachen. Självbedömning eller någon form av återkoppling från lärare till elev ofta under tiden träningspasset pågår. Under varje pass är läraren närvarande och genomför de riktade bedömningshandlingar och anpassningshandlingar som analyseras $i$ den här studien. Analysen innehåller också lärarnas motivering.

\section{RESULTAT}

Här nedan presenteras tre berättelser som illustrerar olika typer av bedömnings- och anpassningshandlingar. Enligt lärarna leder alla dessa handlingar fram till att eleverna tränar på det som läraren anser att eleven behöver för att utveckla sin förmåga att avkoda text. De bedömningar lärarna talar om leder fram till det som lärarna betraktar som "rätt anpassningar", men såväl bedömningar som anpassningar-motiveras på skilda sätt. Den första berättelsen, Att lyssna och utmana, fokuserar på kognitiva bedömningsoch anpassningsaspekter och en anpassningshandling som är inriktad på avkodningens kritiska aspekter. Den andra berättelsen, Att överväga och förenkla, fokuserar på lärarens sökande efter rätt anpassning. I berättelsen beskriver läraren såväl kognitiva som sociala bedömningsaspekter. Den tredje berättelsen, Att göra självständiga anpassningar, handlar om en utmanande undervisningssituation och om en anpassningshandling som går utanför projektets fastställda form. I denna berättelse framträder bedömnings- och anpassningsaspekter av kognitiv och social karaktär. 


\section{Att lyssna och utmana}

När läraren, som undervisar i årskurs 3, uppmanades att berätta hur hon gör för att bedöma och utveckla elevernas avkodningsförmåga beskriver hon hur det kan gå till under momentet som kallas för Uppvärmning. Läraren berättar att hon rör sig runt bland eleverna som läser listor med ord högt för varandra. En del par sitter i klassrummet och andra har fått platser i korridoren eller i ett angränsande grupprum. Hon berättar att hon lyssnar på elevparen som läser och stannar till när hon hör något som väcker hennes intresse. Hon säger att hon är tydlig med sin avsikt till eleven "nu står jag här idag när du gör teknik.träningen, för jag vill höra att du läser orden ordentligt" och markerar på så vis också att syftet med träningen är att läsa noggrant "det är det viktigaste, inte hastigheten”. I citatet nedan berättar hon om två bedömningshandlingar riktade mot elevernas avkodningsförmåga och om två anpassningshandlingar där listorna utvecklas för att passa elevernas fortsatta träning.

[...] när jag hör, när jag lyssnar på eleverna då märker jag ju att de fastnar ju oftast på de här STRRR, och då är det ju de orden som vi ska ta oss förbi för att öka flytet. Så att så, så har jag gått till väga. Sedan har jag elever som växlar vokaler, att man känner inte skillnaden på U och Y till exempel, eller E och I, då har jag tagit sådana ord där man verkligen måste anstränga sig för att se vilken vokal det är. (Lärare årskurs 3)

De båda bedömningshandlingarna handlar om avkodningsförmåga. Läraren beskriver att hon uppmärksammar och bedömer två olika kritiska aspekter i avkodningsträningen. I den första bedömningshandlingen uppmärksammas konsonantkombinationen STR "när jag lyssnar på eleverna då märker jag ju att de fastnar ju oftast på de här STRRR” och att den kan hindra elevernas läsning. Läraren har identifierat en svårighet och använder den som grund för hur arbetet ska anpassas. Anpassningshandlingen som läraren berättar om " då är det ju de orden som vi ska ta oss förbi" syftar på svårigheten med STR och att bokstavskombinationen kan få eleven att fastna i läsningen. Den första anpassningshandlingen inriktas därför på ord som innehåller just den bokstavskombinationen där flera konsonanter ska ljudas samman och som eleverna har svårt för. Att låta eleverna träna på ord som bedöms som svåra ligger i linje med vad tidigare forskning beskriver som framgångsrikt när det gäller att utveckla elevers avkodningsförmåga (Fälth m.fl., 2015; Gustafson m.fl., 2007). Lärarens anpassningshandling innebär att hon för de kommande träningspassen färdigställer en lista som består av ord innehållande STR, och byter ut elevparets tidigare lista mot den nya. Läraren fortsätter att berätta om sitt arbete och motiverar sin anpassningshandling med att den görs "för att öka flytet”. Läraren menar att upprepningen av det svåra STR är det väsentliga. Ju fler gånger eleverna får träna på att avkoda bokstavskombinationen och hur ljuden ska formuleras korrekt desto säkrare på att läsa blir de, flytet ökar. Att 
lärarens anpassning är väl motiverad stödjs inte bara av att hon upplever att flytet i elevernas läsning ökar utan även av Høien och Lundberg (2013) som förespråkar färdighetsträning för att utveckla ortografisk läsning.

Den andra bedömningshandlingen handlar om "elever som växlar vokaler, att man känner inte skillnaden på U och Y till exempel, eller E och I," och synliggör elevernas svårigheter $\mathrm{i}$ att skilja vokalerna åt. Den anpassningshandling som följer naturligt av detta ," då har jag tagit sådana ord", syftar till att träna eleverna att uppmärksamma skillnaderna mellan olika vokaler. Genom att använda ordpar där endast vokalerna utgör skillnaden mellan orden fokuseras elevernas svårigheter. I likhet med den tidigare anpassningshandlingen motiveras denna med att låta eleverna träna sina svårigheter, men nu handlar det om att eleverna ska "anstränga sig för att se vilken vokal det är". Hon motiverar dessa anpassningar med att det gäller att utmana elevernas kognitiva förmågor.

Men jaa, så att jag, jag har gjort lite utmaning åt dem tycker jag med ordlistorna. Det var ju inte de enklaste kanske, utan man var ju verkligen tvungen att ta sig igenom för att det liksom skulle bli lite utmaning för dem som kanske har ganska bra flyt. Så att det inte blev bara läsa på.

(Lärare årskurs 3)

I den här berättelsen motiverar läraren sina anpassningar med att eleverna saknar vissa avkodningsförmågor och att dessa behöver tränas mer noggrant och systematiskt. Motiveringarna handlar således om brister i kognitiv förmåga och att dessa utmaningar möts bäst med anpassningar som stödjer och utmanar eleverna att träna kognitiva förmågor. Lärarens motiveringar har tydlig koppling till såväl teoretiska som praktiska erfarenheter och kompetenser utmärker den professionella läraren (Colnerud \& Granström, 2015).

Sammanfattningsvis är det inte endast träningsuppgifterna som framträder i lärarens berättelse, den förstärks också av ett engagemang som signalerar att Mina elever ska lära sig läsa. Den rätta anpassningen framträder i lärarens motivering och innebär med andra ord uppgifter som låter eleverna träna på specifika detaljer (konsonantkoppling och vokaler) för att utveckla sin avkodningsförmåga, men består också i hög grad av lärarens insatser i stunden. Lärarens motiveringar har tydlig koppling till såväl teoretiska som praktiska erfarenheter och kompetenser vilket utmärker den professionella läraren (Colnerud \& Granström, 2015).

\section{Att överväga och förenkla}

Den här berättelsen handlar om arbetet med avkodning i en förskoleklass. Berättelsen visar att förskollärarens bedömningshandling inrymmer överväganden av såväl sociala som kognitiva aspekter för att hitta rätt anpassning. 
Anpassningshandlingen som följer av dessa avvägningar stödjer enligt läraren elevens avkodningsträning och motiveras främst kognitivt.

Upprinnelsen till berättelsen var en beskrivning av elevernas olika behov och lärarens uttalande att det kan vara svårt att veta hur man ska anpassa träningen i ett klassrum där elever övar på många saker samtidigt. Det framgår av flera berättelser att det ligger ett omfattande bedömningsarbete bakom sammansättningen av arbetsparen och att både sociala och kognitiva aspekter då används av läraren. I ett väl matchat arbetspar är eleverna bekväma i varandras sällskap och kan arbeta koncentrerat tillsammans. Eftersom parens arbete underlättas av att de också arbetar på samma kognitiva nivå framstår detta som eftersträvansvärt för lärarna, men det är inte alltid möjligt att lyckas med. I denna elevgrupp har några elever just börjat intressera sig för bokstäver och ljud, andra kan göra enkla fonem-grafem kopplingar och en del elever kan läsa enkla ord. I citatet nedan berättar hon om sitt arbete med "Uppvärmning". Förskolläraren berättar att listorna som eleverna "värmer upp med" består av allt ifrån enstaka grafem till enklare ord. Arbetet med momentet pågick under ungefär tre minuter. Förskolläraren säger att hon hann gå runt i rummet och att hon rör sig mellan borden där eleverna arbetar i par. Hon observerar att det är något som inte stämmer i ena änden av klassrummet. Ett välfungerande arbetspar borde ägna tiden åt det arbete som hon har planerat, det vill säga att träna avkodning. Nu ser hon att ett par uppför sig på ett störande sätt.

För då liksom märkte man att några jaa...stökade runt lite så då gick jag ju dit och lyssnade lite extra mycket på dom då och då märkte jag ju faktiskt. [...] Jaa alltså då får man ju tänka efter, varför gör det där barnet så där...för att....förstår den inte uppgiften eller är det för lätt eller varför gör den så? Jaaa, ja eller är det den här kombinationen av dom två eleverna som inte är bra, är det därför det inte fungerar eller så. Så kan det ju också vara. Så då fick man liksom observera lite några gånger och titta där, men det där, undrar hur det är där egentligen... O sen...upptäcker man, nämen den där kan ju inte göra det där, det är ju alldeles för svårt, så. Så ja, då fick man byta.

(Förskollärare i förskoleklass)

Av förskollärarens berättelse framgår att hon bedömer en social aspekt, det är elever som "stökade runt lite". Hennes förväntning under den korta tid som passet ska pågå är att eleverna ägnar sig åt träningen som ska utveckla deras avkodningsförmåga. Bedömningshandlingen innebär att hon uppmärksammar att stöket hindrar träningen. Det hade inte varit så förvånande om denna bedömning följts av en tillrättavisning och en anpassningshandling för att få dem att återuppta den avbrutna träningen. Istället berättar läraren om hur hon söker mer information "så då gick jag ju dit och lyssnade lite extra mycket på dom" vilket synliggör hennes vilja och behov av att veta mer. Bedömnings- 
handlingen fortsätter och synliggör svårigheten att veta hur undervisningen ska anpassas och behovet av bättre underlag. Hon berättar att beslutet om att samla in mer information gav resultat "da märkte jag ju faktiskt", som i sin tur leder till att bedömningshandlingen får ett annat fokus. Det betyder att uppmärksamheten på elevernas beteende överges till förmån för en bedömning av andra förmågor som läraren menar har betydelse för avkodningsförmågan. Genom de frågor som läraren berättar om kan vi förstå vad hon ägnar sin uppmärksamhet åt och bedömer"förstär den inte uppgiften eller är det för lätt". Det handlar först om en metodfråga, förstår eleven hur träningen går till? sedan bedömer hon uppgiftens svårighetsnivå och reflekterar över om uppgiften är för enkel. Om så varit fallet kunde en anpassningshandling bestått av att förtydliga uppgiften eller öka svårighetsgraden. Ännu en fråga visar att bedömningshandlingen fortgår. Hon söker vidare och synliggör en ny bedömningsaspekt "är det den bär kombinationen av dom två eleverna som inte är bra" av social karaktär. Om det hade varit aktuellt med en anpassningshandling kopplad till elevernas pararbete hade den kanske handlat om att stödja parets samarbetsförmåga. Av förskollärarens berättelse framgår dock att hon inte finner något stöd för att paret inte kan arbeta tillsammans och den sociala bedömningsaspekten överges. Hon beslutar sig för att samla in mer bedömningsinformation. "Så då fick man liksom observera lite några gånger". Förskolläraren berättar att när hon riktar sitt fokus på bedömning av elevernas avkodningsförmåga $\mathrm{i}$ relation till uppgiftens nivå uppmärksammar hon att "det är ju alldeles för svårt". I början av bedömningshandlingen gjorde läraren en annan bedömning, nu kopplas bedömningshandlingen till elevens avkodningsförmåga vilket vägleder den påföljande anpassningshandlingen. Läraren konstaterar kort "då fick man byta". Anpassningshandlingen framträder som självklar i jämförelse med den tveksamhet som läraren gav uttryck för i bedömningshandlingen. En för svår uppgift byts till en enklare. Även lärarens motivering till den anpassningshandling som hon finner stöd för är kort och lite svårtolkad "nämen den där kan ju inte göra det där". Utifrån sammanhanget kan vi förstå vad förskolläraren berättar, eleven kan inte arbeta med en för svår uppgift, vilket motiverar anpassningshandlingen. Förskollärarens berättelse innehåller även en övergripande fråga som genomsyrar berättelsen "varför gör det där barnet så där?". Frågan visar på lärarens vilja att förstå och framstår som central för det arbete hon gör och motiverar sökandet efter bedömningsinformation som läraren ger uttryck för i berättelsen. Sociala och kognitiva aspekter bedöms, övervägs, överges eller används. Vi menar att det är ett uttryck för den professionella lärarens agerande i sökandet efter vad de menar är rätt anpassning.

Genom förskollärarens överväganden synliggörs komplexiteten som kan inrymmas $i$ en och samma bedömningshandling och de skillnader $i$ anpassning som olika bedömningsaspekter skulle kunna innebära. I berättelsen synliggörs en strategi, en sorts växelverkan, som drivs av lärarens motivering och som 
innebär att läraren genom upprepad informationsinhämtning kan bedöma och undersöka möjliga orsaker till att träningen inte fungerar genom att ta hänsyn till både sociala och kognitiva aspekter av bedömning. Förskollärarens berättelse visar att strategin leder fram till att kognitiva bedömningsaspekter ligger till grund för den anpassningshandlingen som genomförs.

\section{Att göra självständiga anpassningar}

Den här berättelsen innehåller en bedömningshandling där både sociala aspekter och kognitiva förmågor beaktas $\mathrm{i}$ vad som framstår som en växelverkan och ligger till grund för "den rätta" anpassningen, det vill säga en av läraren väl motiverad anpassningshandling i klassrummet.

Läraren, som undervisar i årskurs 2 , berättar att det kan vara en utmaning att få alla elever att delta i Träningslägret och träningspassen som ingår, men att det är meningen att alla elever ska träna. Hon berättar också att deltagandet kan se olika ut. Hon exemplifierar genom att berättar om ett fall, en elev som ofta lämnar klassrummet "han smiter om det är något som inte är så... lockande eller om han inte har lust...eller om han är bungrig eller om det är fint väder ute". Det är enligt läraren svårt att veta varför han gör så. Ibland är eleven inne i skolbyggnaden men inte i klassrummet "Han kan ju sticka liksom, ut $i[\ldots]$...eller stänga in sig $i$ ett torkskåap...eller lägga sig under mattan ...eller ....så”. Eleven hittar på saker som läraren inte har kontroll över, men som påverkar situation i klassrummet och försvårar hans lärande.

Man vet aldrig riktigt vart han är. Så det har ju varit en utmaning för mig. Det är det ju hela tiden i alla ämnen. Men å få honom att "du är också med i den här delen, du är viktig också”. Och han är också... han har ju varit en utav dom som har svårt med läsningen och skrivningen... att få honom att känna Det där vill jag va med på... Och då, då har ju den här appen [...] som är en finsk, nån finska app [...] varit en jättebra grej för honom, för han har aldrig... under dom andra perioderna som jag har haft, lyckats vara med på det här träningslägret. Han har ju alltid försvunnit. [...]. Så i början är det ju väldigt simpelt, [...] till exempel ett bokstavsljud, typ AAA och då ska man hitta det då [...]. Det är lite olika, det är inte enformigt utan det är ju massa olika utmaningar man får. Men så när man kommer vidare i den här världen så blir det ju lite svårare och svårare hela tiden. Det här är ju första gången som han har deltagit, näst intill varje dag. Så det kan ju vara så också, när jag menar vara med. När man lyckas få med även elever som kanske inte brukar delta i undervisning annars, på samma sätt som dom andra.

(Lärare åk 2)

Läraren berättar att tidigare kunskapsbedömningar av elevens läs- och skrivförmåga är en aspekt som är viktig och känd sedan tidigare, " han har ju varit en utav dom som har svairt med läsningen och skrivningen". Men av lärarens 
berättelse framgår att en bedömningshandling endast inriktad på elevens kognitiva förmåga är uppenbart otillräcklig. I bedömningshandlingen inkluderas också den sociala bedömning som läraren tidigare berättat om och som sammanfattas med orden "Man vet aldrig riktigt vart han är. Så det har ju varit en utmaning för mig". Det går inte att undervisa en elev som är borta. Av lärarens citat framgår att bedömningshandlingen grundas på bedömningar gjorda av läraren som även inkluderar erfarenheter från lärarkollegornas tidigare bedömningar där elevens svårigheter uppmärksammats. Lärarens bedömningshandling bygger med andra ord på bedömningar gjorda under en längre tid och av flera olika lärare. De innehåller både kognitiva och sociala aspekter och dessa båda ligger till grund för anpassningshandlingen som innebär att eleven arbetar individuellt, istället för i par, och med en app "som heter Spel-Ett". Appen ersätter materialet som ingår i Träningslägrets olika moment och med hjälp av den kan eleven få en varierad avkodningsträning med inbyggd progression. Lärarens berättelse om appens förtjänster motiverar samtidigt anpassningshandlingen som får eleven att "vara med", delta, om än på sitt vis. I lärarens berättelse uppmärksammas också elevens känsla och egna motivation "att få honom att känna Det där vill jag va med på" som betydelsefull och eftersträvansvärd $i$ valet av anpassning. Lärarens anpassningshandling och motivering ligger $i$ linje med forskningen där hänsyn till sociala aspekter som elevens självförtroende och motivation i samband med läs- och avkodningsträning lyfts. Det framgår av forskningen att en alltför intensiv färdighetsträning, även om den ligger på en kognitivt lämplig nivå, kan rikskera att leda till att elevens motivation för uppgiften minskar (Høien \& Lundberg, 2013). Träning på en för avancerad nivå kan få liknande konsekvenser, det vill säga motivationen för träning sjunker, men kopplas till elevens självförtroende som riskerar att påverkas negativt, vilket kan få till följd att eleven utvecklar olika strategier för att slippa läsa (Taube, 2007).

På ett övergripande plan framträder samstämmigheten mellan bedömningshandling och anpassningshandling vilket också belyser betydelsen av att både kognitiva och sociala bedömningsaspekter beaktas då undervisningen anpassas. Berättelsen belyser också den standardiserade anpassningens begränsningar och hur den överges till förmån för "den rätta anpassningen", det vill säga avkodningsträning som genomförs och därmed enligt läraren kan påverka läsutvecklingen positivt på kort och lång sikt.

\section{DISKUSSION}

Den här studiens övergripande syfte är att bidra med kunskap om lärares arbete med att använda bedömningsinformation som underlag för anpassningar i läsundervisning med fokus på avkodning. Inledningsvis belyser vi hur både sociala och kognitiva aspekter blir betydelsefulla då lärarna berättar om de bedömnings- och anpassningshandlingar de gör i arbetet med att utveckla elevernas avkodningsförmåga inom ramen för Träningslägret. Därefter för vi en diskussion om hur studiens lärare motiverar att 
bedömnings- och anpassningshandlingarna leder till förbättrad avkodningsförmåga och mer specifikt hur lärarnas riktade bedömningar och engagemang framstår som särskilt betydelsefullt för att de ska göra "rätt anpassning". Avslutningsvis följer några implikationer för lärare som undervisar om avkodning samt för forskning $\mathrm{i}$ gränslandet mellan bedömning och avkodning.

Projektet - "Träningslägret" - bygger på tanken att generella bedömningar (H4-test, Kartläggning) och standardiserade anpassningar (till exempel läslistor och parläsning) ska leda till att eleverna utvecklar sin avkodningsförmåga och skolornas egna eftertest indikerar att elevernas avkodningsförmåga förbättras. Av lärarnas berättelser framgår att de gör åtskilliga egna överväganden baserade på egna informella bedömningar som leder till nya anpassningar, vilka enligt lärarna ger högre precision än de standardiserade anpassningarna. Lärarnas berättelser beskriver en variation $i$ vad som bedöms och hur de använder bedömningar för att anpassa sin avkodningsundervisning $\mathrm{i}$ den specifika kontext som träningslägret utgör. I berättelserna framträder både kognitiva- och sociala bedömningsaspekter som centrala för lärarnas anpassningshandlingar. Att de kognitiva aspekterna som fokuserar på bedömningar av avkodningsförmåga bedöms är förväntat och uppmärksammat i tidigare forskning (Fuchs \& Fuchs, 2006; Fälth m.fl., 2015). Att de sociala bedömningarna som handlar om interaktion, elevers beteende och känslor betonas så starkt $i$ berättelserna är lite mindre förväntat eftersom träningslägret, i likhet med andra projekt med syfte att förbättra elevers avkodningsförmåga, främst lyfter fram betydelsen av testresultat då de beskrivs. Ett viktigt resultat från den här studien är således att de sociala bedömningarna som lärarna gör får avgörande betydelse för elevens avkodningsträning. De sociala bedömnningarnas betydelse för anpassningar och lärande är något som uppmärksammats $\mathrm{i}$ tidigare forskning om klassrumsbedömning (jfr Heritage, 2013; McMillan, 2017), även om det inte givits lika stor uppmärksamhet i forskning om avkodning.

Lärarnas motiveringar till vilka anpassningar de gör framstår som förankrade $\mathrm{i}$ forskning om avkodning och färdighetsträning. Projektets planering innehåller övningar som kan ge stöd för kognitiva svårigheter som är vanliga i samband med att unga elever lär sig avkodning (Høien \& Lundberg, 2013). Det handlar främst om fonem-grafem kopplingar, läsflyt, att se skillnader mellan vokaler och om att anpassa genom att förenkla nivån på elevens övningar (Fälth m.fl., 2015; Høien \& Lundberg, 2013). Lärarnas motiveringar till sina mer riktade, eller "skräddarsydda" anpassningar visar att de i sina bedömningar uppmärksammar och identifierar detaljer i elevers kognitiva svårigheter i samband med avkodningen (Gustafson m.fl., 2007; Wolff, 2011; National Reading Panel, 2000). Lärarnas berättelser vittnar om att de ser det som mycket betydelsefullt att listorna med ord är väl anpassade efter de svårigheter som de identifierat. Att bedöma kognitiva aspekter av 
enskilda elevers avkodningsförmåga i samband med själva träningen har enligt forskningen en avgörande betydelse för att läraren ska kunna kalibrera anpassningarna på ett sätt som gynnar elevernas avkodningsförmåga (Fuchs \& Fuchs, 2006; Fälth m.fl., 2015; Høien \& Lundberg, 2013; McMillan, 2017; Wiliam, 2011). Detta resultat är betydelsefullt eftersom det visar att just dessa "avvikelser" från den initiala anpassning som gjordes baserad på testresultatet (H4) kan vara den kanske viktigaste faktorn till att eleverna lär sig att avkoda.

Vid ett ytligt betraktande kan träningslägrets tydliga struktur med generella test och standardiserade anpassningar vara huvudskälet till att eleverna (enligt skolornas egna eftertest) förbättrar sin avkodningsförmåga, men vi menar att lärarnas engagemang $\mathrm{i}$ egna mer intuitiva och individualiserade riktade bedömningar kan vara väl så viktiga. Av lärarnas motiveringar framgår att de är medvetna om de standardiserade anpassningarnas begränsningar och att sökandet efter en tillförlitlig bedömning för att göra den rätta anpassningen är viktigt (Heritage, 2013; McMillan, 2017; Wiliam, 2011). Berättelserna visar att kognitiva och sociala aspekter av bedömning ofta används i en växelverkan som har stor betydelse för lärarens arbete med att hitta rätt anpassning. Denna växelverkan mellan olika bedömningar blir särskilt tydlig i berättelsen om läraren som genom flera bedömningshandlingar och reflektioner runt elevparets stökiga beteende överväger såväl sociala som kognitiva aspekter för att hitta den rätta anpassningshandlingen. Även i berättelsen som ledde fram till en anpassning $i$ form av en app är det tydligt att en rad kognitiva och sociala bedömningshandlingar som flera lärare tidigare genomfört växelverkat för att formulera den bild av elevens behov som sedan ligger till grund för anpassningshandlingen. Sökandet efter den rätta anpassningen handlar alltså inte bara om att överväga olika bedömningsaspekter i realtid, det vill säga under tiden undervisningen pågår (McMillan, 2017; Wiliam, 2011). Det handlar även om att röra sig bakåt $i$ tiden och involvera tidigare lärares olika bedömningar, liksom specialpedagogiska avvägningar. Sådana anpassningar tar $i$ hög grad utgångspunkt $\mathrm{i}$ kunskaper om elevens individuella och specifika behov (Giota, 2002; Gustafsson m.fl., 2007; Taube m.fl., 2015).

\section{Slutsatser}

Det vi ser som viktigt och intressant i sammanhanget är att dessa exempel visar att ett läsutvecklingsprojekt som detta inte kan lyckas utan att lärarna har goda kunskaper, inte bara om läsutveckling och avkodning, utan även om bedömning. Sådana kunskaper ger dem den professionella integritet som gör att de vågar kliva utanför det som de generella bedömningarna visar och de standardiserade anpassningar som förordas. Av lärarnas motiveringar framgår att den rätta anpassningen kan innebära att läraren överger det gemensamma och standardiserade ramverket, för att möta den enskilde elevens behov (Giota, 2002) och hålla fast i det övergripande syftet. Lärarnas professionella kunskaper, förankrade i teoretiska och praktiska erfarenheter (Colnerud \& 
Granström, 2015), framstår som grunden för den framgång som skolorna själva menar att projektet är. Grundade i dessa kunskaper kan projektets gemensamma och standardiserade ramverk fungera som stöd för lärarnas arbete med att anpassa avkodningsundervisningen.

Studiens läsprojekt, betraktat som en praktik som många skolor använder sig av för att stödja lärares arbete, synliggör behovet av ett professionelt handlingsutrymme för lärarna. Studien pekar på vikten av att lärare får möjlighet att göra förfinade och historiskt förankrade bedömningar för att läsprojekt av den här typen ska bli framgångsrika. Kompetenser som vi länkar till professionelt handlingsutrymme och som vi menar framträder i studiens resultat, jämte ämneskunskaper och didaktiskförmåga, är lärarnas förmåga till självreflektion, omdöme och ett etiskt förhållningssätt (jfr lärares yrkesetik, Colnerud \& Granström, 2015). Vi menar att kompetenser som dessa kan vara nog så viktiga för lärare att utveckla, inte minst då de kan bidra till att utveckla en balans mellan elevens behov på kort- och lång sikt och interna och externa krav och förväntningar på lärarens bedömningspraktik.

För lärarstudenter och lärare som undervisar i en liknande kontext hoppas vi att studiens resultat kan bidra med användbar kunskap för vardagspraktiken genom igenkänning. Vi menar också att studiens resultat kan fylla en funktion som underlag för reflektion och diskussion om olika aspekter av framåtsyftande bedömning i tidig läsundervisning och då vara av intresse för lärare och rektorer såväl som för lärarutbildare och skolhuvudmän.

Vi efterfrågar fler studier om lärares intuitiva och individualiserade bedömningar inom ramen för standardiserade ramverk som syftar till att stödja lärarnas arbete med tidig läsundervisning.

\section{TILLKÄNNAGIVANDEN}

Huvudförfattaren har haft huvudansvar och drivit arbetet, medverkat i alla delar, genomfört datainsamling och transkribering av intervjuer. Medförfattaren har medverkat i alla delar utom datainsamling och transkribering.

\section{REFERENSER}

Alatalo, Tarja (2011). Skicklig läs- och skrivundervisning i åk 1-3: Om lärares möjligheter och binder (Doktorsavhandling). Göteborgs universitet.

http://hdl.handle.net/2077/25658

Andersson, Ulrika. B., Löfgren, Håkan, \& Gustafson, Stefan (2019). Forwardlooking assessments that support students' learning: A comparative analysis of two approaches. Studies in Educational Evaluation, 60, 109-116. https://doi.org/10.1016/j.stueduc.2018.12.003 
Castles, Anne, Rastle, Kathleen, \& Nation, Kate (2018). Ending the reading wars: Reading acquisition from novice to expert. Psychological Science in the Public Interest, 19(1), 5-51. https://doi.org/10.1177/1529100618772271

Colnerud, Gunnel, \& Granström, Kjell (2015). Respek.t för lärarprofessionen: om lärares yrkesspråk och yrkesetik. Liber.

Ehri, Linnea C. (2020). The science of learning to read words: A case for systematic phonics instruction. Reading Research Quarterly, 55, 45-60.

https://doi.org/10.1002/rrq.334

Ehri, Linnea C., Nunes, Simone R., Willows, Dale M., Valeska Schuster, Barbara, Yaghoub-Zadeh, Zadeh, \& Shanahan, Timothy (2001). Phonemic awareness instruction helps children learn to read: Evidence from the National Reading Panel's meta-analysis. Reading Research Quarterly, 36, 250-287.

https://doi.org/10.1598/rrq.36.3.2

Elwér, Åsa (2014). Early predictors of reading comprehension difficulties

(Doktorsavhandling). Linköping University Electronic Press.

Fridolfsson, Inger (2016).V allmomodellen. Balanserad läs- och skrivinlärning. Studentlitteratur.

Fuchs, Douglas, \& Fuchs, Lynn S. (2006). Introduction to response to intervention: What, why, and how valid is it? Reading Research Quarterly, 41, 93-99. https://doi.org/10.1598/rrq.41.1.4

Fälth, Linda, Nilvius, Camilla, \& Anvegård, Eva (2015). Intensive Reading with Reading Lists: An Intervention Study. Creative Education, 6, 2403-2409. https://doi.org/10.4236/ce.2015.622246

Giota, Joanna (2002). Skoleffekter på elevers motivation och utveckling. Pedagogisk forskning i Sverige, 7(4), 279-279.

Goodson, Ivor F., \& Sikes, Pat J. (2001). Life history research in educational settings: Learning from lives. Open University Press.

Gough, Philip B., \& Tunmer, Wiliam E. (1986). Decoding, reading, and reading disability. Remedial and special education, 7(1), 6-10. https://doi.org/10.1177/074193258600700104

Grigorenko, Elena L. (2009). Dynamic assessment and response to intervention: Two sides of one coin. Journal of Learning Disabilities, 42, 111-132.

Gustafson, Stefan, Ferreira, Janna, \& Rönnberg, Jerker (2007). Phonological or orthographic training for children with phonological or orthographic decoding deficits. Dyslexia, 13(3), 211-229. https://doi.org/10.1002/dys.339

Heritage, Margaret (2013). Gathering evidence of student understanding. Sage handbook of research on classroom assessment. SAGE Publications. https://doi.org/10.4135/9781452218649.n11

Hirsh, Åsa, \& Lindberg, Viveca (2015). Formativ bedömning på 2000-talet-en översikt av svensk och internationell forskning. Vetenskapsrådet. 
Hjetland, Hanne N., Brinchmann, Ellen I., Scherer, Ronny, \& Melby-Lervåg, Monica (2017). Preschool predictors of later reading comprehension ability: A systematic review. Campbell Systematic Reviews, 13(1), 1-155.

https://doi.org/10.4073/csr.2017.14

Hjetland, Hanne N., Lervåg, Arne, Lyster, Solveig A. H., Hagtvet, Bente E., Hulme, Charles, \& Melby-Lervåg, Monica (2019). Pathways to reading comprehension: A longitudinal study from 4 to 9 years of age. Journal of Educational Psychology, 111(5), 751-763. https://doi.org/10.1037/edu0000321

Høien, Torleiv, \& Lundberg, Ingvar (2013). Dyslexi Från teori till praktik. Natur \& Kultur.

Jönsson, Anders (2017). Prov eller bedömning?: att tolka och använda provresultat och omdömen. Gleerup.

Labov, William, \& Waletzky, Joshua (1967/1997). Narrative Analysis: Oral Versions of Personal Experience. I Michael Bamberg (gästred.). Oral versions of personal experience: three decades of narrative analysis. Journal of Narrative and Life History, 7(1-4), 3-38. https://doi.org/10.1075/jnlh.7.02nar

Lindberg, Viveca, Eriksson, Inger, \& Pettersson, Astrid (red.) (2019). Formativ bedömning: Utmaningar för undervisningen. Natur \& Kultur.

Lonigan, Christopher J., Burgess, Stephen R., \& Schatschneider, Christopher (2018). Examining the simple view of reading with elementary school children: Still simple after all these years. Remedial and Special Education, 39(5), 260-273. https://doi.org/10.1177/0741932518764833

Lundberg, Ingvar, \& Herrlin, Katarina (2014a). God läsutveckling: kartläggning och örningar. Natur \& Kultur.

Mavrommatis, Yiannis (1997). Understanding assessment in the classroom: Phases of the assessment process - the assessment episode. Assessment in Education:

Principles, Policy \& Practice, 4(3), 381-400. https://doi.org/10.1080/0969594970040305

McMillan, James H. (2017). Classroom assessment: Principles and practice that enhance student learning and motivation. Pearson.

Mishler, Elliot. G. (1999). Storylines. Craftartists' Narratives of Identity. Harvard University Press (s. 1-52).

Morgan, Paul L., \& Fuchs, Douglas (2007). Is there a bidirectional relationship between children's reading skills and reading motivation?. Exceptional children, 73(2), 165-183. https://doi.org/10.1177/001440290707300203

National Reading Panel. (2000). Teaching children to read: An evidence-based assessment of the scientific research literature on reading and its implications for reading instruction. The National Institute of Child Health and Human Development. Hämtad 20191115. https://www.nichd.nih.gov/sites/default/files/publications/pubs/nrp/Documen ts/report.pdf 
Pettersson, Daniel. (2010). Internationella kunskapsmätningar och deras funktioner. I C.

Lundahl och M. Folke-Fichtelius (red.), Bedömning i och av skolan, (s. 259-273).

Studentlitteratur. https://doi.org/10.33063/diva-427674

Pérez Prieto, Hector. (2006). Historien om räven och andra berättelser. Om klasskamrater och skolan på en liten ort - ur ett skol- och livsberättelseperspektiv. Karlstad University Studies 2006:52. https://doi.org/10.24834/isbn.9789178770687

Prøitz, Tine S., Mausethagen, Sølvi, \& Skedsmo, Guri (2017). Investigative modes in research on data use in education, Nordic Journal of Studies in Educational Policy, 3(1), 42-55. https://doi.org/10.1080/20020317.2017.1326280

Sadler, Royce. D. (1989). Formative assessment and the design of instructional systems. Instructional science, 18(2), 119-144. https://doi.org/10.1007/bf00117714

SFS 2010:800. Skollag.

Skolverket. 20210408. Bedömningsstöd svenska/svenska som andraspråk grundskolan - Skolverket

Skolverket. (2019). Läroplan för grundskolan, förskoleklassen och fritidshemmet 2011:

Reviderad 2019 (6 uppl.). https: / /www.skolverket.se/getFile?file=4206

Snow, Catherine E., \& Juel, Connie (2005). Teaching Children to Read: What Do We Know about How to Do It? I Margarete J. Snowling \& Charles Hulme (red.), Blackwell handbooks of developmental psychology. The science of reading: $A$ handbook (s. 501-520). Blackwell Publishing. https://doi.org/10.1002/9780470757642.ch26

Taube, Karin (2007). Läsinlärning och självförtroende: psykologiska teorier, empiriska undersökningar och pedagogiska konsekvenser. Nordstedts Akademiska Förlag.

Taube, Karin, Fredriksson, Ulf, \& Olofsson, Åke (2015). Kunskapsöversikt om läsoch skrivundervisning för yngre elever (Vetenskapsrådets delrapport).

Vetenskapsrådet.

https://www.vr.se/download/18.2412c5311624176023d25b34/1555424813359/

Kunskapsoeversikt-om-laes-och-skrivundervisning-foer-yngre-

elever_VR_2015.pdf

Westlund, Barbro (2013). Att bedöma elevers läsförståelse: en jämförelse mellan svenska och kanadensiska bedömningsdiskurser i grundskolans mellanår (Doktorsavhandling). Natur \& Kultur.

Vetenskapsrådet (2017). God forskningssed. Vetenskapsrådet. https://www.vr.se/download/18.2412c5311624176023d25b05/1555332112063/ God-forskningssed_VR_2017.pdf Hämtad 2020-06-26

Wiliam, Dylan (2011). Embedded formative assessment. Solution Tree Press.

Wolff, Ulrika (2011). Effects of a randomised reading intervention study: An application of structural equation modelling. Dyslexia, 17(4), 295-311. https://doi.org/10.1002/dys.438

Wolff, U. (2016). Effects of a randomized reading intervention study aimed at 9year-olds: A 5-year follow-up. Dyslexia, 22(2), 85-100. 


\section{Övriga källor}

Attagardenslasprojekt. (Hämtad 2020-06-05) https://docplayer.se/48988469-

Attagardskolans-lasprojekt-for-okad-lasformaga-ordkunskap-och-lasgladje.html

Burlövskommun. (Hämtad 2020-06-05)

https://burlov.se/download/18.3d6b838b15b14f211844515b/1490953585487/L

$\%$ C3\%A4sprojekt $\% 20$ Svensh $\%$ C3\%B6gskolan.pdf

Gerby skola.(Hämtad 2020-06-05) http://www.kjellstaffans.fi/material/lasmodellfor-gerby-skola/

Lundberg, Ingvar \& Herrlin, Katarina (2014b). God läsutveckling. Stockholm. Natur \& Kultur. (Hämtad 2020-06-10)

https://www.smakprov.se/smakprov/?isbn=9789127437517\&partner=smakprov

LegiLexi.se.(Hämtad2020-06-05) https://legilexi.org/om-oss/

Lasrorelsen.nu. (Hämtad 2020-06-05) http://www.lasrorelsen.nu/wordpress/wpcontent/uploads/KORT-INFORMATION-OM-LÄSRÖRELSEN.pdf

Nationellt bedömningsstöd i läs- och skrivutveckling för årskurs 1-3. (Hämtad 2020-06-10) https://bp.skolverket.se/web/bs_gr_grgrsve01_1-3

Pedagogstockholm.se. (Hämtad 2020-06-05)

http://pedagogblogg.stockholm.se/tourahagnesten/tag/avkodning/

Pedagoguddevalla.se.(Hämtad 2020-06-05) https://www.uddevalla.se/utbildningoch-barnomsorg/grundskola/skolutveckling/pedagog-uddevalla/skolutvecklinggrundskola/2018-08-22-lasprojekt-i-arskurs-2.html 